\section{Energy document lists laboratory roles, not goals}

Washington. The operations of the Department of Energy (DoE)'s laboratory network have been spelt out in unprecedented detail in a draft "strategic mission plan" that was released by the department in Washington last week.

But Charles Curtis, deputy energy secretary, warned that the document fell considerably short of the department's goal of creating a mission plan for the laboratories, which, he said, would take time. "To make this into a true, living strategic plan for the laboratories is going to take the next year or so," he said. The draft plan, he said, "describes how things are. It does not describe where we should go."

Curtis also admitted that the detailed information in the plan could be construed as "an invitation to make mischief", as it contains much explicit information on the exact role of the laboratories. About 150 different programmes in both nuclear weapons and non-weapons areas across the department are described, along with details of how money for each one is distributed between the laboratories.

To take one example at random, the plan explains that the DoE spends $\$ 2$ million on research into carbon dioxide in the atmosphere, with 90 per cent of it to the Oak Ridge Laboratory in Tennessee. Pressure groups opposed to such research will be now be able to focus their protests on the laboratory, safe in the knowledge that laboratories outside are not directly involved.

The plan - which was demanded last year by a commission, chaired by the industrialist Robert Galvin, which investigated the future of the laboratories, and drawn up by the new Laboratory Operations Board - contains a new mission statement for the laboratories.

It also seeks to categorize each laboratory's role in each mission, identifying "principal laboratories" that do more than 20 per cent of a programme, "major contributing laboratories" that do more than 10 per cent, and "specialized participating laboratories" that do less than that. But no effort is made to change or set directions for these roles.

Some members of the Secretary of Energy's Advisory Board, which received the plan last week, complained that it lacked information on how the laboratories should make better use of industry and the universities for research - a charge which Curtis accepted. "Other things being equal," he said, the department should "favour the universities" as a place to do research, because of their teaching role. "We are not just in the business of defending the federal laboratories."

Colin Macilwain

\title{
NIH clinical research plans under fire from Republicans
}

Washington. Republicans in the US Congress have attacked President Bill Clinton's 1997 budget proposals for the National Institutes of Health (NIH), saying that the administration's plans outlined in the budget to build a new clinical research facility would be at the expense of grant money for individual scientists.

John Porter (Republican, Illinois), the chairman of the House of Representatives appropriations subcommittee that oversees the NIH budget, last week called the president proposal "phoney" and "irresponsible", and said that the level of new research money it requests is "clearly not acceptable." Porter added:

A spokeswoman for Porter's counterpart in the Senate, Arlen Specter (Republican, Pennsylvania), said that the Senator had similar concerns about the impact of this decision on the extramural research programme. "[Specter] is supportive of the Clinical Research Center, but he's concerned because so much of the [new] money goes there," said Margaret Camp. Specter chairs the Senate Appropriations Committee subcommittee which oversees the NIH.

Once the $\$ 310$ million that the president requested for the new 250-bed clinical facil-

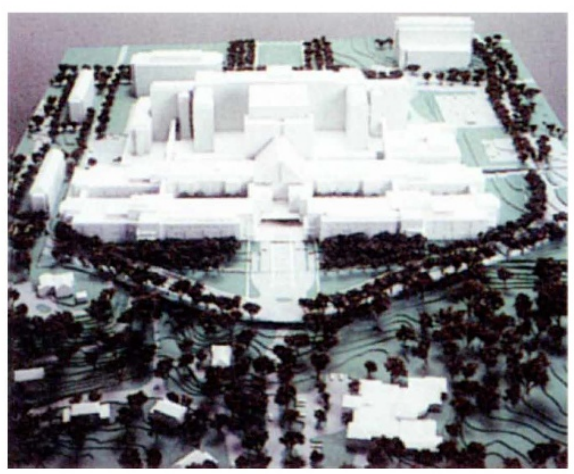

Clinical model: centre as envisaged by Zimmer Gunsul Frasca Partnership.

ity is deducted from next year's budget request, the rest of NIH would, under the president's plan, receive an increase of only 1.6 per cent over 1996. Porter said that as an alternative, he would seek a 6.5 per cent increase in research funding, in addition to the money earmarked for the new Clinical Research Center (CRC).

But Clinton administration officials robustly defend the request. "The president has been very aggressive in trying to bolster NIH research, and the 1997 budget reflects that," says Lawrence Haas, a spokesman for the Office of Management and Budget, pointing out that Clinton has budgeted hundreds of millions for the clinical centre "in an era of very scarce resources". He adds: "If the other side is concerned with research, what's the problem with a Clinical Research Center?"

John Gibbons, the director of The White House's Office of Science and Technology Policy emphasized at a briefing last weck that there was a need to "accelerate" building the CRC to replace a decrepit 1953 facility. Harold Varmus, the director of $\mathrm{NIH}$, argued separately that the president's budget still provides a shot-in-the-arm for individual investigators. "We have enough of an increase for us to pay more grants in 1997. The important thing is keeping the number of new awards up," he said.

In the budget request for the fiscal year beginning 1 October, sent to Congress on 19 March, President Clinton asked for $\$ 467$ million in new funding for the NIH, boosting the biomedical agency's 1996 budget by 3.9 per cent, to $\$ 12.41$ billion. Sixty per cent of the new money would be used to build the CRC, an 850,000-square-foot addition to the NIH's existing clinical facility, parts of which would be converted to other purposes. Completion is planned for early next century.

The administration proposes that most ( 86 per cent) of the rest of the new money be used to support non-NIH scientists, providing with a 2.6 per cent increase overall in biomedical grant funding for non-NIH scientists. This would include 207 new research project grants. Intramural scientists, meanwhile, would lose 0.2 per cent of their 1996 funding, while research and development contracts would fall by 0.9 per cent.

But even some of the external scientists warn that laying out $\$ 310$ million for the $\mathrm{CRC}$ in a single fiscal year may cause an uneven flow of funds for multi-year grants downstream. "Instead of having a smooth flow you have something of a roller coaster," says Ralph Bradshaw, the president of the Federation of American Scientists for Experimental Biology, which last month recommended a 6.5 per cent increase in NIH funding over 1996. Spreading the $\$ 310$ million for the CRC over three years would probably be "more to our liking."

Asked whether he supported the size of the $\$ 310$ million request for the $\mathrm{CRC}$, and its disbursement in a single fiscal year, Porter said that the main purpose of hearings was "to get at the authenticity and credibility of the figures." The subcommittee on labour, health and human services, and education of the House Appropriations Committee has scheduled a hearing on the CRC for 23 April. The Senate subcommittee plans to begin hearings on the NIH budget on 16 May.

The president's budget proposal also calls for the Office of AIDS Research (OAR) to maintain control over the NIH's $\$ 1.4$ billion AIDS research budget. Meredith Wadman 